\title{
Experimentally Induced Testicular Alterations in Boars: Hormonal Changes in Mature and Peripubertal Boars
}

\author{
By Lena Malmgren \\ Department of Obstetrics and Gynaecology and Department of Clinical Chemistry, Swedish \\ University of Agricultural Sciences, Uppsala, Sweden.
}

\begin{abstract}
Malmgren, L.: Experimentally induced testicular alterations in boars: Hormonal changes in mature and peripubertal boars. Acta scand. vet. 1990, 31, 97-107. Eleven sexually mature boars and 10 peripubertal boars were used to study the effects of elevated testicular temperature on plasma hormonal levels. The scrotum of the boars was covered with a textile-aluminium foil insulation device for $100 \mathrm{~h}$. Insulation of the scrotum in the peripubertal boars took place at an age of 100 days.

Blood samples were drawn 3 times daily for 12 days in the mature boars, starting 3 days before scrotal insulation. In the peripubertal boars, blood sampling was performed once a day for 11 days, starting the first day of scrotal insulation.

During scrotal insulation, the plasma levels of testosterone, oestradiol-17 $\beta$ and oestrone sulphate decreased continuously in the mature boars. After removal of the scrotal insulation device there was a continuously increase, back to normal levels of oestradiol-17 $\beta$ and oestrone sulphate. The plasma levels of testosterone showed an immediate rise of brief duration after removal of the device in 5 of the boars, while in the other 6 boars the rise in testosterone levels came 4 days after removal and lasted for 3 days.

In the peripubertal boars, there were no significant differences in the hormone levels between the experimental and control animals during and after scrotal insulation. However, the decrease in testosterone concentration over time, during scrotal insulation, was significant within the experimental group.
\end{abstract}

Boar; mature; peripubertal; testosterone; oestradiol-17 $\beta$; oestrone sulphate.

\section{Introduction}

Various environmental factors are known to influence gonadal function. Prolonged stress in man was found to have a suppressive effect on plasma testosterone concentrations (Aakvaag et al. 1978). Decreased testosterone concentrations were also seen in boars (Larsson et al. 1983) and in rams (Gomes 1971) after heat stress.

The testes of boars and stallions are very active in producing oestrogens, and particularly oestrogen sulphate is present in high concentrations in the peripheral plasma in these species. Oestrogens are formed in testicular tissue by conversion of testosterone (Setchell 1978).

Experimentally induced cryptorchidism in rats (Berg \& Damber 1978) caused a great reduction in testosterone levels in the abdominal testicle. Mazzarri et al. (1968) and Holst (1949) showed that local heating of the scrotum caused alterations in the seminiferous epithelium, but they did not study the hormonal patterns. We have developed a reliable method for scrotal insulation which elevates the scrotal surface temperature $3-5^{\circ} \mathrm{C}$. Boar testis exposed to such a high surface temperature develop degenerative changes 
in the seminiferous epithelium (Malmgren \& Larsson 1989). These changes are accompanied by altered sperm morphology for about 6 weeks (Malmgren 1989) in mature boars. In peripubertal boars, maturation of the testicular function was delayed if scrotal insulation was performed around the time of onset of spermatogenesis, i.e. at an age of 100 days (Malmgren 1989).

Florcruz \& Lapwood (1978), Allrich et al. (1982) and Ford (1983) studied the endocrine changes occurring during sexual maturation in boars under normal conditions. There seems to be differences in the testosterone secretion patterns as various studies have indicated a presence (Claus \& Gimenez 1977, Kattesh et al. 1982) or absence (Brock \& Wetteman 1976, Lapwood \& Florcruz 1978, Edqvist et al. 1980) of a diurnal testosterone secretion pattern.

To our knowledge no study has been performed on the effect of elevated scrotal temperature after scrotal insulation in peripubertal or mature boars on hormone secretion. Although it is obvious and well known that increased scrotal temperature causes degeneration of the seminiferous epithelium, the underlying mechanisms are still poorly understood. Since hormonal changes have been found to occur after exposing boars to heat stress it is important to study the endocrine effects of local scrotal heating, avoiding exposure to any external stress on the animals. The purpose of this study was to describe the temporal changes in peripheral plasma concentrations of testosterone, oestradiol-17 $\beta$ and oestrone sulphate during and after scrotal insulation in mature and peripubertal boars.

\section{Material and methods \\ Animals}

Eleven sexually mature Swedish Landrace experimental boars (8-12 months of age) and
10 peripubertal (6 experimental and 4 control animals) crossbred (Swedish Landrace/Swedish Yorkshire) boars were used in the study. Seven of the mature boars and 8 of the peripubertal boars were also used for studies of the semen and sperm morphology (Malmgren 1989). The animals were kept in a barn at an ambient temperature of approximately $18^{\circ} \mathrm{C}$. The mature boars were kept in individual pens. The peripubertal boars, which originated from 3 different litters, were penned together. All boars were fed a commercial feed used for finishing pigs in Sweden. Scrotal insulation was performed as previously described (Malmgren \& Larsson 1989).

\section{Blood sampling}

In the mature boars permanent vein catheters were placed in the jugular vein and passed subcutaneously to the animals back ( $R O$ driguez \& Kunavongkrit 1983). Blood samples were drawn via the catheters, without restraining the animals, 3 times daily (9 a.m., noon, 3 p.m.) for 12 days, starting 3 days before scrotal insulation. In the peripubertal boars blood sampling was performed once a day for 11 days, starting on the first day of scrotal insulation when the boars were 100 days of age. The blood samples were taken from the jugular vein, using heparinized vacutainer tubes, while the boars were restrained. The blood samples were collected in heparinized tubes, immediately centrifuged and the plasma was harvested and stored at $-20^{\circ} \mathrm{C}$ until assay.

\section{Hormone assays}

All the hormone analyses were carried out by radioimmunoassay, at the Department of Clinical Chemistry, Swedish University of Agricultural Sciences.

Antiserum to testosterone was raised against testosterone-3-(O-carboxymethyl)oxime-b- 
ovine serum albumin. The crossreactivity of this antiserum with other related steroids indicated significant crossreaction with $5 \alpha$-dihydrotestosterone $61 \%$ and androstenedione $7 \%$ (Oltner et al. 1979). The inter-assay coefficient of variation was $7 \%$ at an average concentration of $18.9 \mathrm{nmol} / \mathrm{l}$ ).

Oestradiol-17 $\beta$ was determined using an antiserum against 6-ketooestradiol-17 $\beta-6-(0-$ carboxy-ethyl)oxime-bovine serum albumin which crossreacted $11 \%$ with oestrone (Boilert et al. 1973, Lindberg et al. 1974). The inter-assay coefficient of variation was $16 \%$ and $7 \%$ at average concentrations of 25.7 and $112.2 \mathrm{pmol} / \mathrm{l}$, respectively.

Oestrone sulphate was determined using an antiserum against oestrone glucosiduronatebovine thyreoglobulin (Wright et al. 1978). The antiserum crossreacted with oestrone $62.5 \%$, 2-hydroxoestrone $24.3 \%$, oestradiol-17 $\beta \quad 15.9 \%$, oestrone-glucosiduronate $10.7 \%$ and oestradiol-3-glucosiduronate $2.6 \%$ (Wright et al. 1978). The inter-assay coefficient of variation was $8 \%$ and $10 \%$ at average concentrations of 9.6 and 14.1 nmol/l, respectively.

All hormone concentrations reported represent the mean of duplicate determinations.

\section{Statistical analysis}

The checking and handling of the data as well as the statistical analysis were carried out using the Statistical Analysis System (SAS Institute Inc. 1985).

For the mature boars, the hormone levels were analysed using analysis of variance, according to a model including the effects of boar and sampling day.

For the peripubertal boars, the hormone levels were analysed for each sampling day, using analysis of variance, according to a model including the effects of group and boar within group.

The samples collected during scrotal insula- tion (days 1 to 5) were analysed, for each group of boars, according to a model including the effects of boar and regression on day identity. In the above model, the effect of boar was regarded as random. Levels of significance are expressed conventionally: $\mathrm{p}<0.05^{*}, \mathrm{p}<0.01^{* *}, \mathrm{p}<0.001^{* * *}$.

\section{Results}

\section{Mature boars}

The average levels of testosterone decreased continuously during scrotal insulation from $14.5 \mathrm{nmol} / 1$ to $7.5 \mathrm{nmol} / \mathrm{l}$. The testosterone levels during scrotal insulation differed significantly from the preexperiment concentration (Fig. 1a). Also the decrease over time during scrotal insulation was significant (regression coefficient $=-1.07 * * \mathrm{nmol} / \mathrm{l} / \mathrm{day}$ ). After removal of the scrotal insulation device the changes in the hormonal concentrations showed 2 different patterns among the boars. Five of the boars got an immediate and brief rise in testosterone on the day following removal of the scrotal device. (Fig. 1b). The rise in testosterone concentrations in the other 6 boars came 4 days after removal of the device and lasted for 3 days (Fig. 1b). It should be mentioned that the latter group of boars had higher average testosterone levels during the whole scrotal insulation period than the former group.

Concentrations of oestradiol-17 $\beta$ and oestrone sulphate are shown in Figs. 2 and 3. Both hormones decreased continuously during scrotal insulation, and the concentrations were significantly lower than the pretreatment level during most days of scrotal insulation. Oestradiol-17 $\beta$ decreased from $236 \mathrm{pmol} / \mathrm{l}$ to $173 \mathrm{pmol} / \mathrm{l}$ and oestrone sulphate decreased from $43 \mathrm{nmol} / \mathrm{l}$ to 17 nmol/l, respectively, from the day before the start of treatment to day 5 of treatment. After removal of the insulation device concentrations of both hormones began to in- 


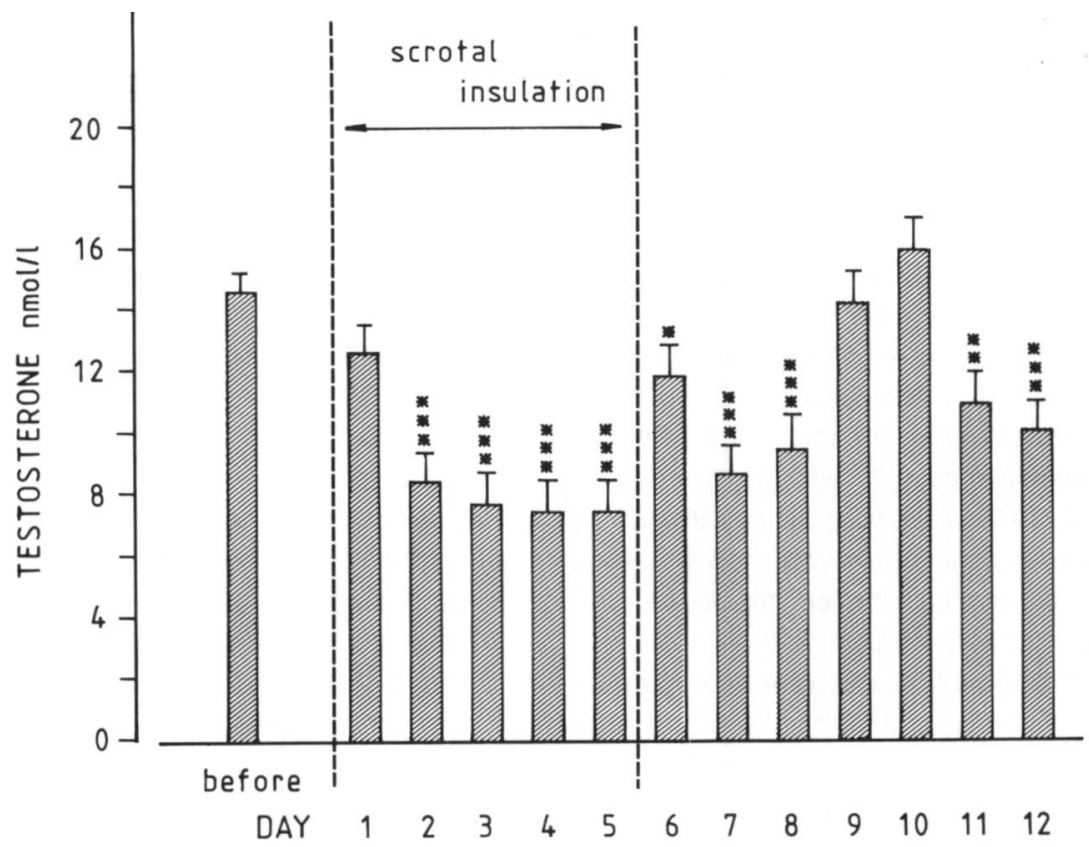

Figure 1a. Daily least squares means levels of testosterone before, during and after scrotal insulation in the mature boars. The »before« value refers to least squares means the 3 days ( 3 samples a day) before scrotal insulation. ${ }^{*}=p<0.05, * * p<0.01$ and $* p<0.001$, compared with "before« value.

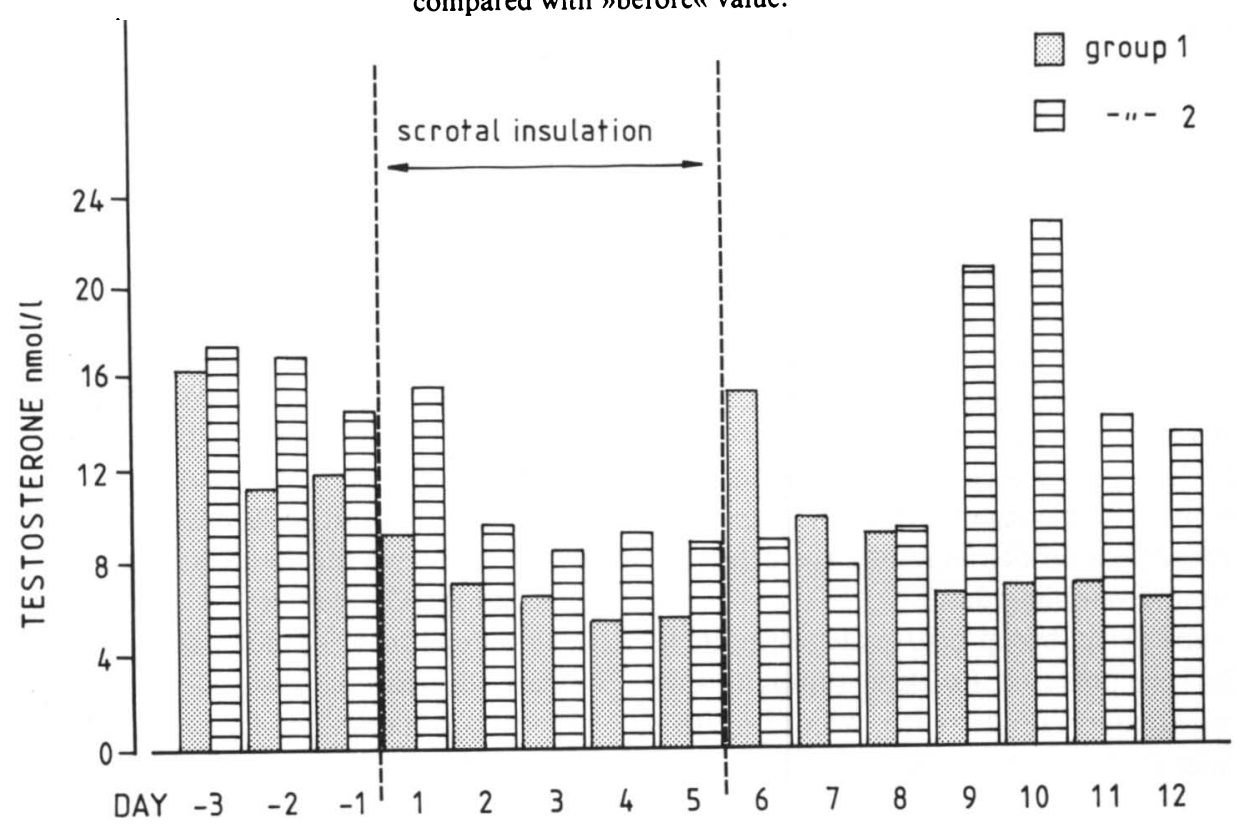

Figure 1b. Daily means in the 2 groups of mature boars with different hormonal patterns after scrotal insulation. Group $1=5$ boars. Group $2=6$ boars. 


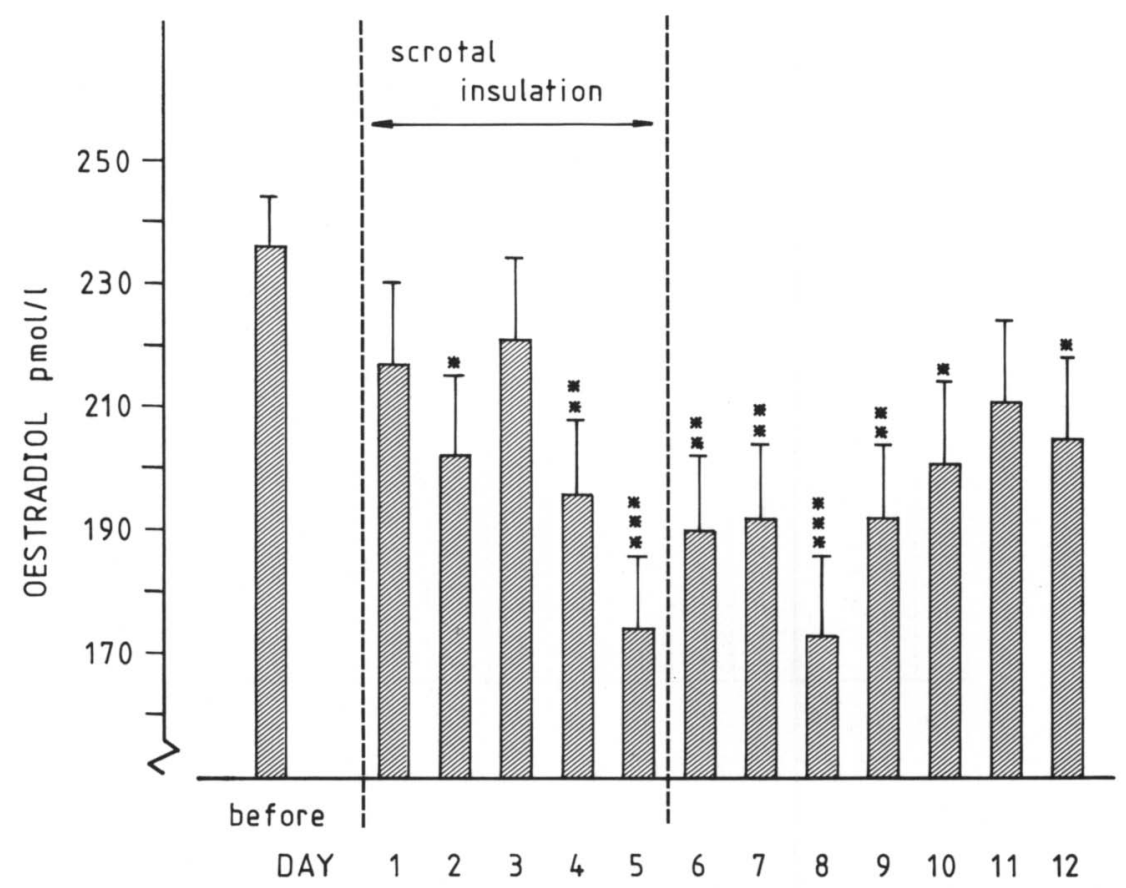

Figure 2. Daily least squares means levels of oestradiol-17 $\beta$ before, during and after scrotal insulation in the mature boars. The »before « value refers to least squares means the 3 days (3 samples a day) before scrotal insulation. $*=p<0.05, *=p<0.01$ and * $\mathrm{p}<0.001$, compared with »before« value.

crease and a day 6 after removal, no significant differences, compared with pretreatment levels, were seen. The levels of oestradiol-17 $\beta$ and oestronesulphate were then 211 $\mathrm{pmol} / \mathrm{l}$ and $40 \mathrm{nmol} / \mathrm{l}$, respectively.

\section{Peripubertal boars}

The daily least-squares means for testosterone, oestradiol-17 $\beta$ and oestrone sulphate in the peripubertal boars during and after scrotal insulation is given in Figs. 4-6.

Testosterone concentrations in the experimental group decreased during scrotal insulation, from $8.8 \mathrm{nmol} / 1$ to $4.6 \mathrm{nmol} / \mathrm{l}$, but the decrease was not significant compared with the control group. However, the decrease over time during scrotal insulation was significant within the experimental group (regression coefficient $=-1.33$ * nmol/1/day). After removal of the scrotal insulation device testosterone was almost similar in both groups (ranging from 4.0 $\mathrm{nmol} / 1$ to $7.2 \mathrm{nmol} / \mathrm{l}$ ) (Fig. 4).

There were no significant differences in oestradiol-17 $\beta$ and oestrone sulphate between the control and experimental animals. Oestradiol-17 $\beta$ in the experimental group ranged from $53.3 \mathrm{pmol} / 1$ to $95.5 \mathrm{pmol} / 1$ and in the control group from $75 \mathrm{pmol} / 1$ to 109.0 pmol/l (Fig. 5). Oestrone sulphate ranged from $19.5 \mathrm{nmol} / 1$ to $45.0 \mathrm{nmol} / 1$ in the experimental group and from $19.0 \mathrm{nmol} / \mathrm{l}$ to 36.0 $\mathrm{nmol} / \mathrm{l}$ in the control group (Fig. 6). 


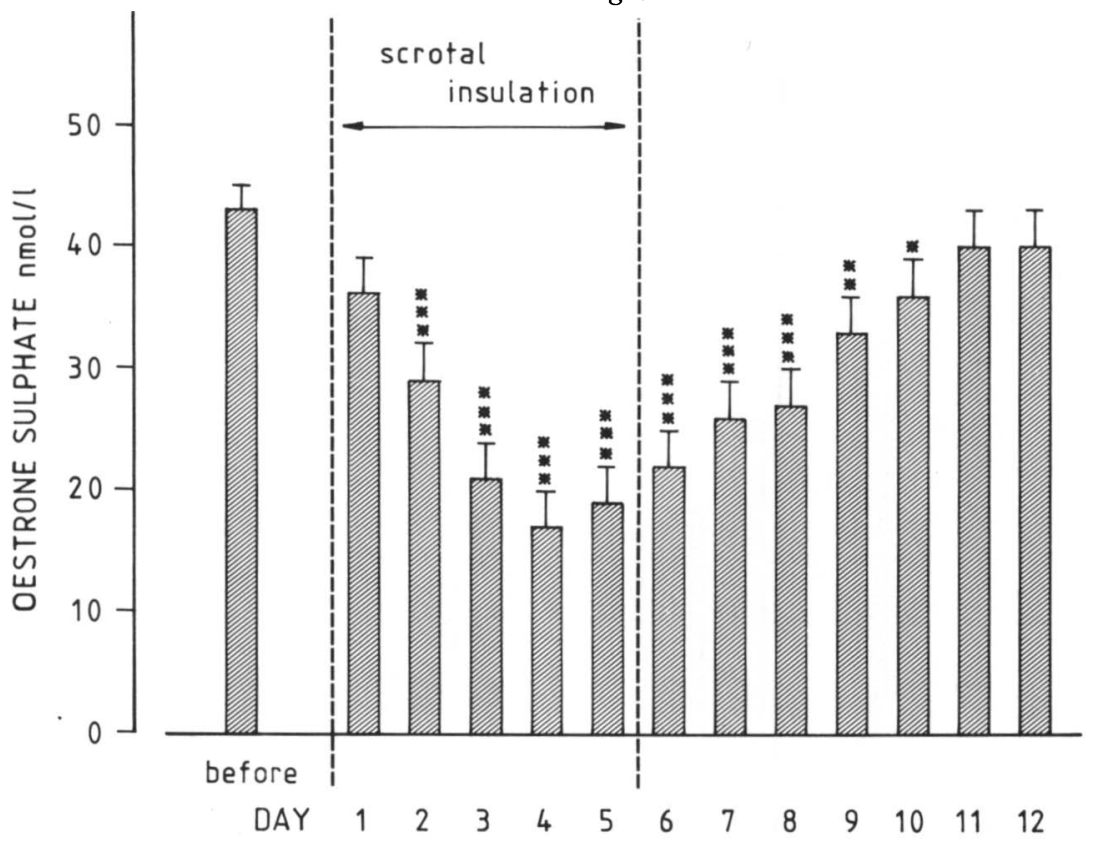

Figure 3. Daily least squares means of oestrone sulphate before, during and after scrotal insulation in the mature boars. The »before « value refers to least squares means the 3 days ( 3 samples a day) before scrotal insulation. ${ }^{*}=p<0.05, *=p<0.01$ and $* *=p<0.001$,

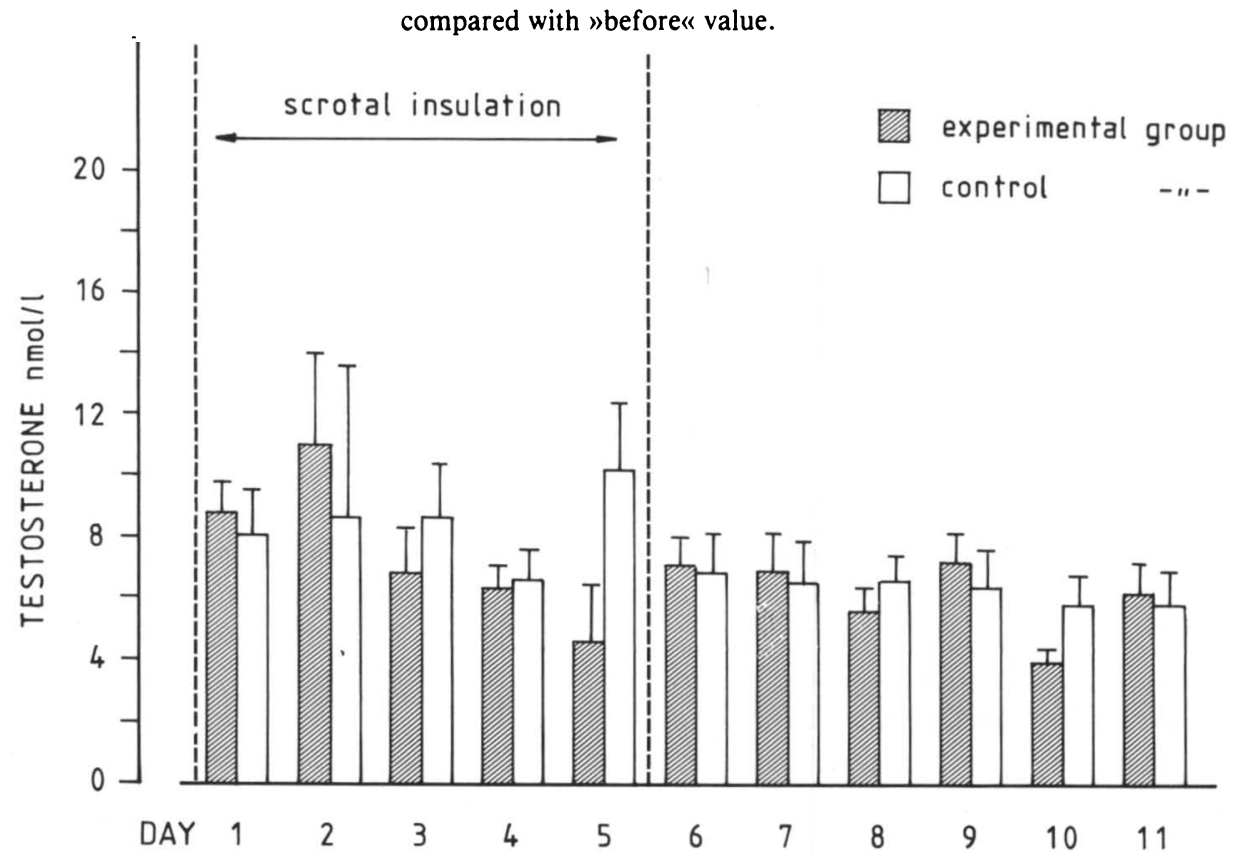

Figure 4. Daily least squares means levels of testosterone for experimental (scrotal insulation) and control peripubertal boars. No significant differences were seen between the groups. A significant decrease over time, during scrotal insulation, was seen within the experimental group. 


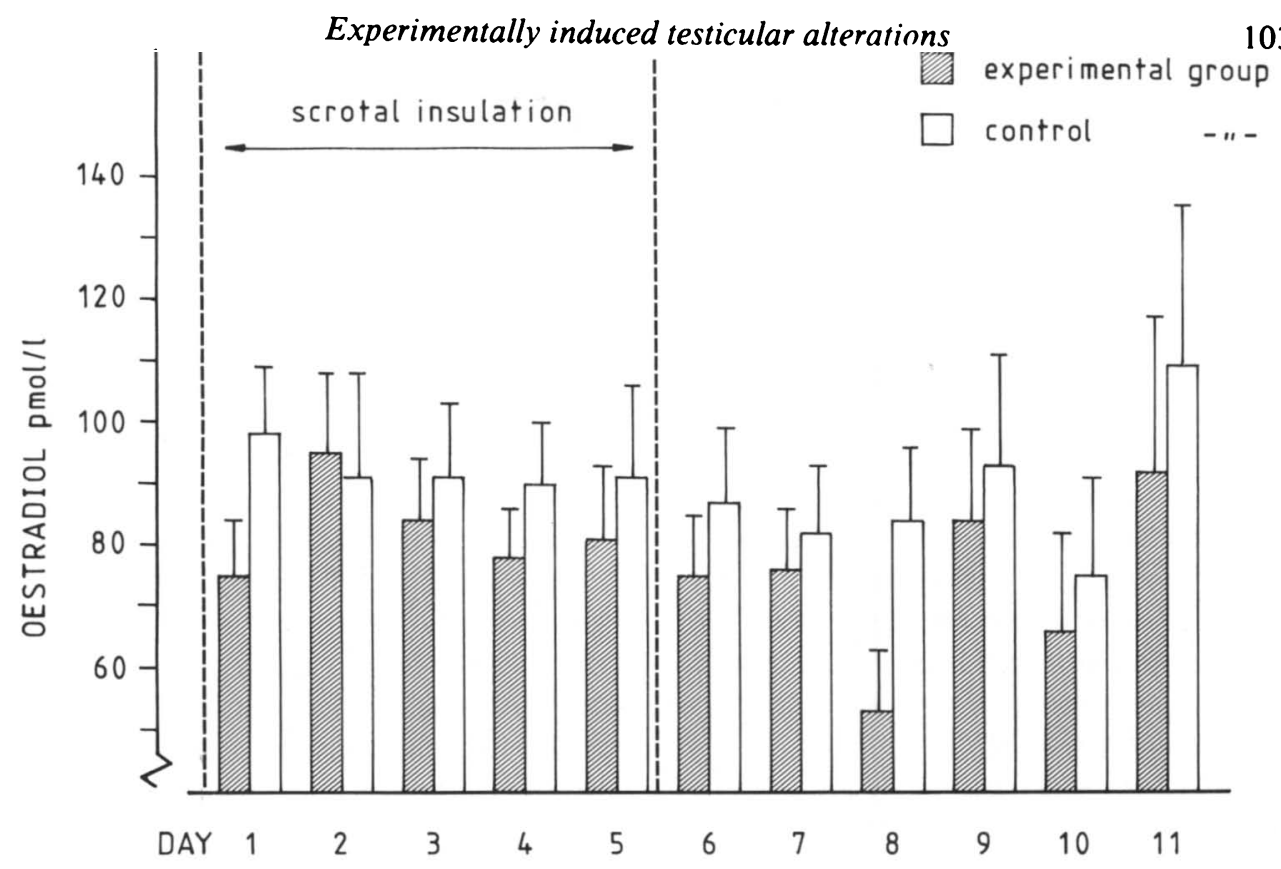

Figu re 5. Daily least squares means levels of oestradiol-17ß for experimental (scrotal insulation) and control peripubertal boars. No significant differences were seen between the groups.

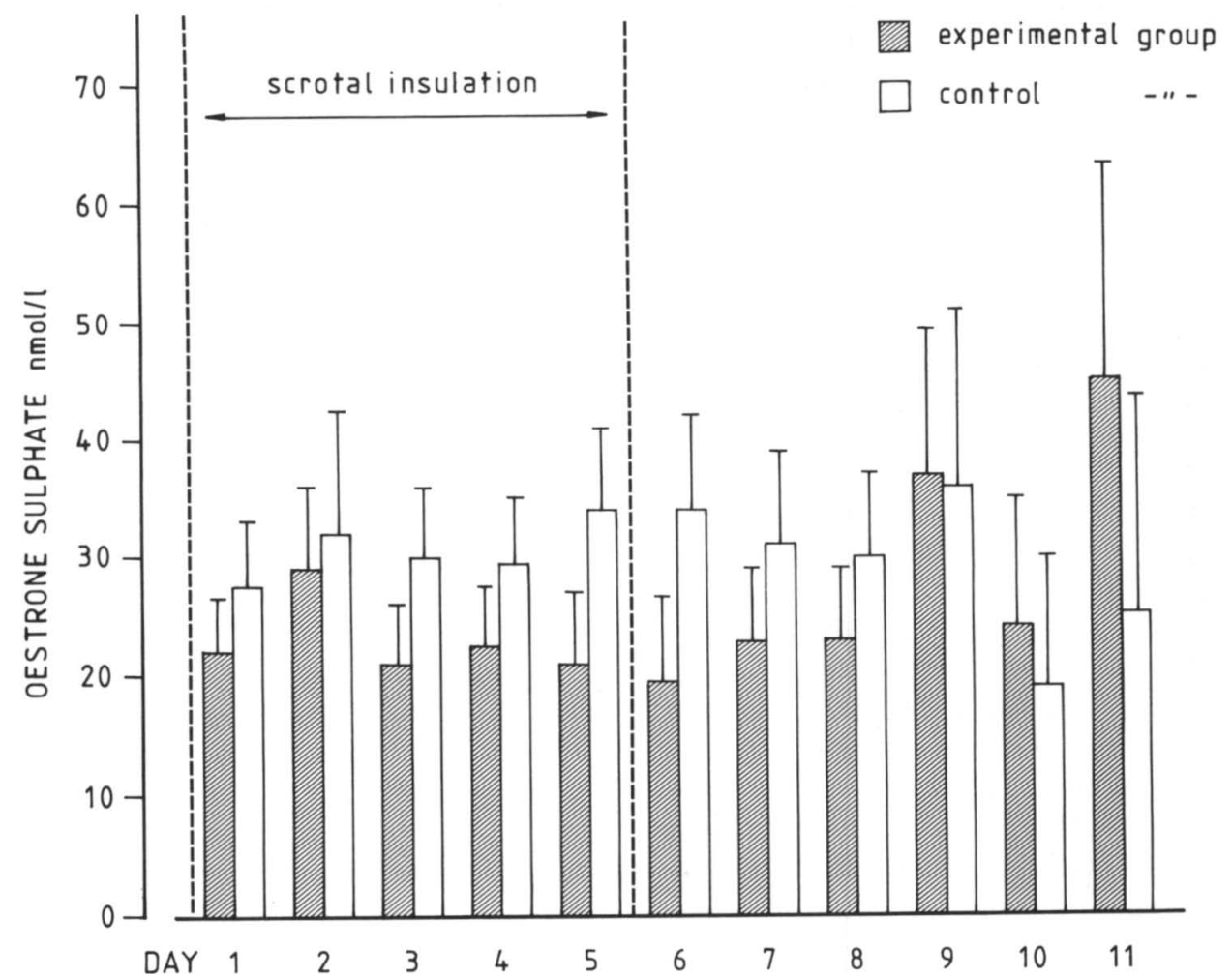

Figure 6. Daily least squares means of oestrone sulphate for the experimental (scrotal insulation) and the control groups. No significant differences were seen between the groups. 


\section{Discussion}

The decrease in plasma testosterone concentrations during scrotal insulation in the mature boars is in agreement with previous experiments with boars exposed to heat stress (Wetteman \& Desjardin 1979, Larsson et al. $1983)$. They are also in accordance with findings in rams after stress exposure (Gomes et al. 1971) or challenge with endotoxin (Wallgren et al. 1989). A marked suppressive effect on plasma testosterone levels was seen in men exposed to prolonged physical and psychological stress, (Aakvaag et al. 1978). In boars treated with ACTH for 5 days reduced testosterone concentrations were observed (Liptrap \& Raeside 1975).

In the present study using only insulation of the scrotum and in which the boars were maintained in a familiar environment, one may assume that the stress factor on the animals was minimal. Thus, plasma cortisol levels may remain unaffected and should not cause a reduction in the plasma testosterone secretion. It seems more likely that the changes in testosterone secretion are caused by a direct effect of the higher temperature on the testis. This was previously found by Berg \& Damber (1978), Damber et al. (1978) in rats, and Skinner \& Rowson (1968) in lamb and calves, where lowered testosterone concentrations in experimentally induced cryptorchidism indicated impaired Leydig cell function.

The elevated testosterone found after termination of the scrotal insulation is most likely intended to compensate for the lowered levels observed during scrotal insulation. The pattern, including the variations among boars, is very similar to the results after heat stress exposure (Larsson et al. 1983). It is interesting to note that the testosterone elevation occurred later and lasted longer in boars which had comparatively higher testosterone levels during scrotal insulation. This may indicate an individual decreased sensitivity to increased temperature and also less need for compensatory testosterone production. The decrease in oestradiol-17 $\beta$ and oestrone sulphate concentrations is likely to be due to the lower testosterone production, since oestrogens are synthesized from androgens (Dorrington et al. 1978) in the testicles. If the androgen concentration, e.g. testosterone and androstenedione, is lowered the conversion rate to oestrogens may decrease. Reaside \& Renaud (1983), suggested that oestrogen production in the boars is due mainly to the steroidogenic capacity of the Leydig cells. Another explanation could be impaired Sertoli cell function, caused by the elevated temperature, since Dorrington et al. (1978) suggested that the synthesis of oestrogens takes place in the Sertoli cells influenced by FSH. Hagenäs \& Ritzen (1976) showed that after experimentally induced cryptorchidism in the rat the production of seminiferous fluid decreases indicating that the Sertoli cell secretory function was impaired by the elevated temperature. However, under the experimental conditions used it can only be stated that elevated scrotal temperature in the mature boars caused lowered peripheral concentrations of both testosterone and oestrogens.

Age and maturity seemed to influence the endocrine response. There were no significant differences between the peripubertal experimental and control boars when comparison was made within days. There was, however, a significant decrease in plasma testosterone levels, during scrotal insulation, over time within the experimental group. Plasma oestrogen levels showed only small differences between the experimental and control animals. The explanation could be that the samples were taken at around 100 days of age. At this age spermatogenesis begins (Florcruz \& Lapwood 1978) and the en- 
docrine system involving the testes is very active. Oestrogen and testosterone concentrations increase continuously as the pubertal development progresses (Florcruz \& Lapwood 1978, Allrich et al. 1982). Allrich et al. (1982) suggested that there is a higher sensitivity of the hypothalamus/pituitary to the negative steroid feedback controlling $\mathrm{LH}$ at this age. It is further suggested that the metabolic clearance rate of testosterone may be lower during the peripubertal period.

Another and equally plausible explanation of the minor endocrine response among the peripubertal boars may be the scheme and procedure used for blood sampling. The one sample per day procedure with restraining of the animals may have masked substantial endocrine alterations. This short stress situation could induce high cortisol levels and an increase in testosterone concentrations (Liptrap \& Raeside 1975, Juniewicz \& Johnson 1981). It was originally planned that the peripubertal boars should be sampled in exactly the same way as the older boars. Preliminary attempts, however, showed that the problem with infected permanent vein catheters was so great that this method had to be abandoned for the young boars. Similar problems never occurred with the mature boars. In an additional experiment boars were treated with testosterone propionate for 4 weeks (Malmgren 1988). The dosage levels were chosen so that peripheral plasma testosterone levels were maintained within the ranges found in the present study before scrotal insulation. This plasma level probably gives a negative feed back to the hypothalamus/pituitary glands, which leads to a decrease in LH release. It may be assumed that the boars treated in this way had substantially lowered intratesticular testosterone levels (Huang \& Nieschlag 1984). Yet, their semen production and sperm morphology remained unaffected. The reduced te- stosterone production during heat stress or scrotal insulation is thus not likely to be the direct cause of the changes found in the seminiferous epithelium and sperm morphology. It seems more likely that the endocrine changes, as well as the changes in the seminiferous epithelium, both result from the increased testicular temperature.

\section{Acknowledgement}

This investigation was supported by grants from the Swedish Council for Forestry and Agricultural Research. The author are indebted to Prof. Kjell Larsson, Prof. Stig Einarsson and Prof. Lars-Eric Edqvist for discussions and criticism, Nils Lundeheim, $\mathrm{PhD}$, for his help with statistical analysis and Mrs. Mari-Anne Carlsson for technical assistance.

\section{References}

Aakvaag A, Bentdal O, Quigstad K, Walstad P, Ronningen $H$, Fonnum $F$ : Testosterone and testosterone binding globulin (TeBG) in young men during prolonged stress. Int. J. Androl. 1978, 1, 22-31.

Allrich RD, Christenson RK, Ford JJ, Zimmerman $D R$ : Pubertal development of the boar: testosterone, estradiol-17 $\beta$, cortisol and LH concentrations before and after castration at various ages. J. Anim. Sci. 1982, 55, 1139-1146.

Berg A, Damber JE: Morphometric and functional investigation on the Leydig cells in experimental unilateral cryptorchism in the rat. Int. J. Androl. 1978, 1, 549-562.

Boilert B, Edqvist L-E, Johansson EDB, Lindberg $P$, Martinsson $K$ : The influence of conjugated estrogens in radioimmunoassays using different antibodies against oestradiol-17ß. Steroids 1973, 22, 891-894.

Brock $L W$, Wetteman RP: Variations in serum testosterone in boars. J. Anim. Sci. (Abstr.) 1976, 42, 244-245.

Claus $R$, Gimenez $T$ : Diurnal rhythm of $5 \alpha$-androst16-en-3-one and testosterone in peripheral plasma of boars. Acta Endocr. 1977, 84, 200-206.

Damber J-E, Berg A, Janson PO: Testicular blood flow and testosterone concentrations in the spermatic venous blood in rats with experimental cryptorchidism. Acta Endocr. 1978, 88, 611-618. 
Dorrington JH, Fritz IB, Armstrong DT: Control of testicular estrogens synthesis 1978, 18, 55-64.

Edqvist LE, Einarsson S, Larsson $K$, Lundström $K$ : Diurnal variations in peripheral plasma levels of testosterone, androstenone and cortisol in boars. Acta vet. scand. 1980, 21, 451-453.

Florcruz $S V$, Lapwood KR: A longitudinal study of pubertal development in boars. Int. J. Androl. 1978, 1, 317-330.

Ford JJ: Serum estrogen concentrations during postnatal development in male pigs. Proc. The Soc. Exper. Biol. and Med. 1983, 174, 160-164.

Gomes WR, Butler WR, Johnson AD: Effect of elevated ambient temperature on testis and blood levels and in vitro biosynthesis of testosterone in the ram. J. Anim. Sci. 1971, 33, 804-807.

Hagenäs L, Ritzen EM: Impaired Sertoli cell function in experimental cryptorchidism in the rat. Mol. Cell. Endocr. 1976, 4, 25-34.

Holst S: Sterility in boars. Nord. Vet.-Med. 1949, I, 87-120.

Huang HFS, Nieschlag E: Alteration of free sulphydryl content of rat sperm heads by suppression of intratesticular testosterone. J. Reprod. Fert. 1984, 70, 31-38.

Juniewicz $P E$, Johnson $B H$ : Influence of adrenal steroids upon testosterone secretion by the boar testis. Biol. Reprod. 1981, 25, 725-733.

Kattesh HG, Knight JW, Gwazdauskas FC, Kornegay ET: Daily alterations in plasma testosterone in boars at different ages. Theriogenology, 1982, 18, 113-118.

Lapwood $K R$, Florcruz $S V$ : Luteinizing hormone and testosterone secretory profiles of boars: effects of stage of sexual maturation. Theriogenology, 1978, 10, 293-306.

Larsson K, Einarsson S, Lundström K, Hakkarainen $J$ : Endocrine effects of heat stress in boars. Acta. vet. scand. 1983, 24, 305-314.

Lindberg BS, Lindberg P, Martinsson K, Johansson $E D B$ : Radioimmunological methods for the estimation of oestrone, oestradiol-17 $\beta$ and oestriol in pregnancy plasma. Acta Obstet. Gynaecol. 1974, Suppl. 32, p 5-19.

Liptrap RM, Raeside JI: Increase in plasma testosterone concentration after injection of adrenocor- ticotrophin into the boar. J. Endocr. 1975, 66, 123-131.

Malmgren $L$, Larsson $K$ : Experimentally induced testicular alterations in boars; histological and ultrastructural findings. J. Vet. Med. Serie A. 1989, 36, 3-14.

Malmgren L: Experimentally induced testicular alterations in boars; sperm morphology changes in mature and peripubertal boars. J. Vet. Med. Serie A. 1989, 36, 411-420.

Malmgren L: Experimentally induced testicular alterations in boars. Thesis, Uppsala, 1988.

Mazzarri G, du Mesnil, du Buisson F, Ortavant $R$ : Action of temperature and light on spermatogenesis, sperm production and fertility of the boar. Proc. VIth Int. Congr. Anim. Reprod. and A. I. Paris 1968, 1, 305-308.

Oitner $R$, Lundström $K$, Edqvist L-E: LH and testosterone in monozygous growing bulls. Swedish J. agric. Res. 1979, 9, 151-161.

Raeside JI, Renaud RL: Estrogen and androgen production by purified Leydig cells of mature boars. Biol. Reprod. 1983, 28, 727-733.

Rodriguez $H$, Kunavongkrit $A$ : Chronical venous catheterization for frequent blood sampling in unrestrained pigs. Acta vet. scand. 1983, 24, 318320.

SAS Institute Inc.: SAS user's guide, SAS Institute Inc. Cary, N.C. 1985.

Setchell B: The mammalian testis. Elek Books limited. London. 1978, p. 109-180.

Skinner JD, Rowson LE: Some effects of unilateral cryptorchism and vasectomy on sexual development of the pubescent ram and bull. J. Endocr. 1968, 42, 311-321.

Wallgren $M$, Kindahl $H$, Larsson $K$ : Clinical, endocrinological and spermatological studies after endotoxin in the ram. J. Vet. Med. Serie A. 1989, 36, 90-103.

Wetteman RP, Desjardins $C$ : Testicular function in boars exposed to elevated ambient temperature. Biol. Reprod. 1979, 20, 235-241.

Wright K, Collins DC, Musey PI, Preedy JRK: A specific radioimmunoassay for estrone sulphate in plasma and urine without hydrolysis. J. clin. Endocr. Metab. 1978, 47, 1092-1098. 


\section{Sammanfattning}

Experimentellt framkallad testikeldegeneration hos galt: hormonella förändringar hos könsmogna och pubertala galtar.

Elva könsmogna och 10 peripubertala galtar användes för att studera effekten av förhöjd testikeltemperatur på hormonnivåerna i blodet. Skrotum täcktes med en värmeisolerande páse i 100 tim. Pà de unga galtarna skedde skrotumisoleringen vid 100 dagars álder. Blodprov togs frản de kơnsmogna galtarna 3 ggr/dagl. i 12 dagar, med början 3 dagar innan skrotumisoleringen. Från de peripubertala galtarna togs blodprov 1 gång dagl. i 11 dagar, med början samma dag som skrotumisoleringen startade.

Under skrotumisoleringen av de könsmogna galtar- na sjönk perifera plasmanivåerna av testosteron, östradiol-17ß och östron-sulfat. När isoleringen togs bort ökade niváerna av östradiol-17 $\beta$ och östronsulfat succesivt tillbaka till ursprungvärdena. Plasmanivåerna av testosteron uppvisade en snabb ökning med kort duration efter avtagandet av skrotumisoleringen hos 5 av galtarna, medan hos de andra 6 kom ökningen 4 dagar senare och varade i 3 dagar.

Hos de peripubertala galtarna var det ingen signifikant skillnad, beträffande hormonnivảerna, mellan experiment och kontrolldjuren under och efter skrotumisoleringen. Däremot var sänkningen av testosteronnivåerna över tiden signifikant hos experimentgruppen under skrotumisoleringen.

(Accepted April 24, 1989).

Reprints may be requested from: Lena Malmgren, Department of Obstetrics and Gynaecology, Faculty of Veterinary Medicine, Box 7039, S-750 07, Uppsala, Sweden. 